\title{
KAREL FREDERIK WENCKEBACH
}

This great Dutch physician, to whose memory a tribute is now paid, was born at The Hague on March 24, 1864. He proceeded from the Gymnasium to the University of Utrecht and in 1888 graduated doctor of medicine with a thesis entitled "Over den bouw en de ontwikkeling der Bursa-Fabricii." While still in Utrecht he began those brilliant researches on extrasystoles, conduction defects, allorrhythmia, and alternation that were published between the years 1898 and 1901 . By critical analysis of arterial pulse tracings, before the advent of the polygraph or electrocardiograph, he was the first to show that those disturbances of the human heart represent disorders of properties inherent in the myocardium and are of the same nature as those known to occur in the experimental animal. That great achievement was his alone and, together with Mackenzie's studies of the venous pulse, it initiated a new era in cardiology. The functional activity of the heart in health and disease, its response to drugs, its very structure had now to be studied anew. This in turn paved the way for a wider and better knowledge of other factors than the heart that promote the circulation of the blood and interstitial fluid. Wenckebach was indeed one of the foremost leaders in the renaissance of clinical medicine at the dawn of this century.

Two years after his appointment to the Chair of Medicine in Groningen in 1901, the publication of his first and greatest work "Die Arhythmie als Ausdruck bestimmter Funktionsstörungen des Herzens" brought him world-wide fame. In 1911 he passed to the Chair of Medicine in Strasburg and in 1914 to that in Vienna, where a great medical school had been founded, two centuries earlier, by another Dutchman, van Swieten; a pupil of Boerhaave. All Wenckebach's work was characterized by keen clinical acumen, by the utmost precision, and by close correlation of clinical research with that in the laboratory. Graduates were drawn to his clinic from many lands, and notably from the United States. He resigned his chair in 1929.

In addition to his epochal work on cardiac irregularity, of which there is an English translation, he wrote on the radiography of the chest, artificial pneumothorax, beri-beri, circulatory failure, and other subjects. His chief contributions to medical literature between 1898 and 1924 are given in "Die unregelmassige Herztatigkeit," the monumental treatise of which he and Winterberg were the joint authors. A further list is given on page 143. He was a founder and one of the editors of the "Wiener Archiv für innere Medizin." Three terms bear his name: Wenckebach's periods, the slowing of auriculoventricular conductivity with periodic dropping of ventricular beats; Wencke- 


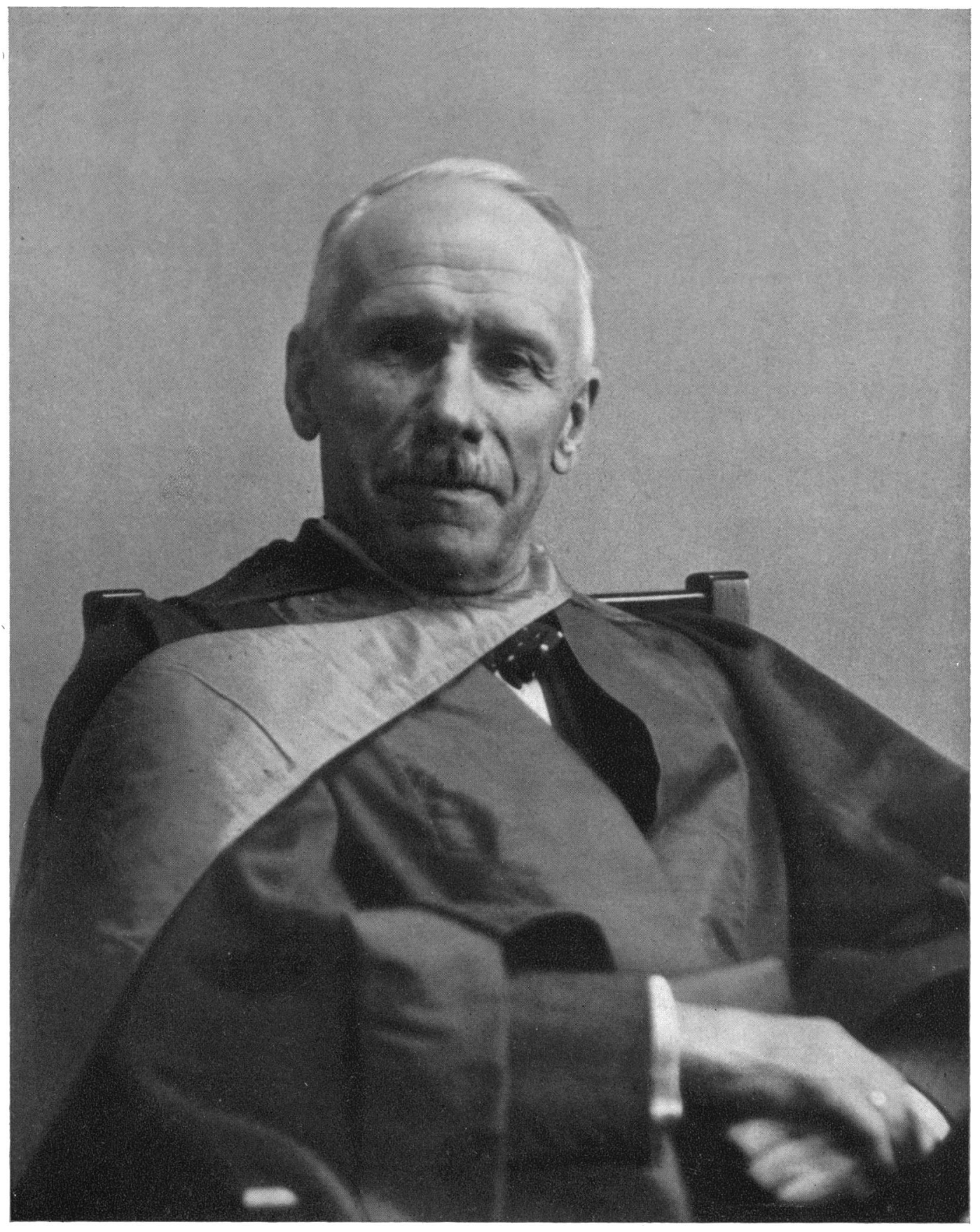


bach's sign, the paradoxical movements of the chest in chronic mediastinopericarditis; and Wenckebach's bundle, a band of muscle passing from the superior vena cava to the right auricle.

Wenckebach always felt at home in our country, closely akin to his native land. As a young man he visited Mackenzie in Burnley, and while Gibson's guest in Edinburgh was the central figure of some amusing but apocryphal tales. He opened a discussion on digitalis in London in 1910, and that on heart failure at the Seventeenth International Congress of Medicine in London in 1913. In 1919, when Eastern Europe had been laid waste and destitution and disease were rife, he initiated the Relief Mission to Vienna. In 1928 he was a delegate to the tercentenary celebration in London of the publication of "De motu cordis" and was the St. Cyres Lecturer at the National Hospital for Diseases of the Heart. In the following year he delivered an oration at the sesqui-centenary celebration of the Birmingham General Hospital. In 1930 he received the honorary degree of LL.D. from the University of Edinburgh; he made a tour through the Highlands and a pilgrimage to the Research Institute founded by his friend, Sir James Mackenzie, in St. Andrews. Three years later he was again in Edinburgh as the Gibson Memorial Lecturer at the Royal College of Physicians.

Many honours were bestowed upon him. He was awarded the Order of Merit of the Austrian Republic, was a Fellow of the Koninklijke Akademie van Wetenschappen te Amsterdam and of the Kaiserliche Akademie der Wissenschaften, an Honorary Fellow of the Royal College of Physicians of London, the Royal College of Physicians of Edinburgh, the Royal Faculty of Physicians and Surgeons of Glasgow, and the Royal Society of Medicine, an Honorary Member of the Medico-Chirurgical Society of Edinburgh and the Cardiac Society of Great Britain and Ireland, and a Corresponding Foreign Member of la Société Française de Cardiologie.

The charm of the English countryside and the gaiety of Franz Hals' canvases appealed strongly to Wenckebach for he was a lover of beauty in nature and art. He was a warm-hearted man with a keen sense of humour. Among his many friends he counted Gibson, Clifford Allbutt, Osler, Keith, and Cushny. He was a modest man, saying "In medical science there are vast realms of which I have no special knowledge" and, again, "No, I am not a great man; I am a happy man." His particular charm was a radiant joie de vivre and to him the wine and salt of life were given in full measure.

\section{W. T. RitchiE.}

\section{A Further Note of Wenckebach's Medical Contributions}

1. Beiträge zur Entwicklungsgeschicte der Knochenfische. Arch. mikrosk. Anat., 1886, 28.

2. Ueber den Pulsus Alternans. Z. klin. Med., 1902, 44, 218.

3. Ueber an der Atrioventrikulargrenze ausgelöste Systolen bei Menschen (with James Mackenzie). Arch. Anat. u. Phys. (Phys. Abt.), 1905, 235. 
4. Les Irrégularites du Coeur. Arch. Mal. Coeur, 1908, 1, 65.

5. Ueber Heilung des chronischen (tuberculösen) Empyems mittelst künstlichem Pneumothorax. Mitt. Grenzgeb. Med. u. Chir., 1909, 19, 842.

6. Herzinsufficienz und Herzschwäche. XVIIth Internat. Congr. Med., 1913, Sect. VI, 187.

7. The Radiology of the Chest. Arch. Roent. Ray., 1913-14, 18, 169.

8. Cinchona Derivatives in the Treatment of Heart Diseases. J. Amer. med. Ass., 1923, 81, 472.

9. Angina Pectoris and the Possibilities of its Surgical Relief. Brit. med. J., 1924, 1, 809.

10. Toter Punkt, "Second Wind," and Angina Pectoris. Wien. klin. Wschr., $1928,41,1$.

11. Heart and Circulation in a Tropical Avitaminosis (Beri-beri). Lancet, 1928, 2, 265.

12. The Use of Foxglove at the Bedside. Brit. med. J., 1930, 1, 181.

13. Herz und Kreislauf-insuffizienz. Dresden and Leipzig, 1930. (Third Edit., 1934.)

14. The Riddle of the Beri-beri Heart. Libman Ann. Vol., 1932, 3, 1197.

15. Das Beri-beri-Herz. Berlin and Wien, 1934.

16. Stossdämpfer im Herzen. Z. Kreisl., 1938, 30, 441. 